\title{
NETWORKS OF FREEDOM: NETWORKS OF CONTROL
}

\author{
David Garcia \\ Dean of College Chelsea College of Art and Design \\ 16 John Islip Street \\ London \\ UK \\ dgarcia@chelsea.arts.ac.uk \\ http://www.chelsea.arts.ac.uk/ \\ http://www.tacticalmediafiles.net/
}

In 1996 the usually sober minded political scientist Manuel Castells, wrote about the revolution in popular networked computing in momentous terms. "We are witnessing", he declared "the formation of a hypertext and a meta-language which for the first time in history, integrate into the same system the written, oral and audiovisual modalities of human communication The human spirit reunites its dimensions in a new interaction between the two sides of the brain, machines and social contexts. For all the science fiction ideology and commercial hype surrounding the so-called information superhighway we can hardly underestimate its significance". 1

However inflationary this rhetoric now sounds, for some of us the significance went even further into the realm of the political. In the 90's I and many other radical media artists felt ourselves to be part of a utopian moment, a moment characterised by what became known as the 'hacker' ethic in which it was believed that challenging the domains of forbidden knowledge would lead to a new kind of society based on participatory communications. Historical context played its role in fuelling these dreams. The power some of us attributed to this 'new media politics' was influenced by role that all forms of media appeared to have played in contributing to the collapse of the Soviet Union. It seemed as though old style armed insurrection had been superseded by digital dissent and media revolutions. It came to be believed that top down power had lost its edge. As late as 1999 in his Reith lecture, Anthony Giddens could still confidently assert that 'The information monopoly upon which the Soviet system was based had no future in an intrinsically open framework of global communications'.

The myth of a triumphant computer mediated popular democracy continues in the newly minted lexicon of web 0.2 , crowd sourcing and all the other high tech means for harvesting so called 'user generated content'. From Wikipedia to The X Factor, the basic premise remains stubbornly intact, with its claim that technology has ushered in a new era of participatory freedom. The purpose of this paper is not only to critique these assumptions by examining some of their founding myths but also to ask what if anything can be recuperated from the hacker ethic and its utopian origins. 
My way of addressing this question is to interrogate one of the core assumptions, which drive these cultures, the assumption that the emergence of new forms of human freedom based on openness or transparency are the result of the decentralised structure of the technologies of the network society.

The continued dominance of this supposition is in part the result of the persistence of one of the most powerful myths of the information age; the myth that knowledge that will set you free. This founding narrative of techno-culture visible from Ted Nelson 'Computer Lib'2 onwards, upgrades for the technological era the age old proposition that knowledge and freedom are not only connected but may actually entail one another.

The fact that a belief in the necessary relationship between knowledge and freedom has gone largely unquestioned is based in part on the depth of its lineage, 'ancient stoics and most modern rationalists are at one with Christian teaching on this issue'. And 'ye shall know the truth and the truth shall make you free'. As Isaiah Berlin pointed out in 1968, 'This proposition is not self evidently true, if only on empirical grounds.' It is, he asserted, 'one of the least plausible beliefs ever entertained by profound and influential thinkers.' 3 The accompanying rhetoric of transparency, freedom, access, participation, has come to constitute the ideological foundation of our era.

\section{TOOLS OF CONTROL}

Whatever counter evidence is presented there is something stubbornly persistent idea that freedom (and by association democracy) has been transformed ever since its fate became associated with the Internet. And creative computing, has in its turn, been reconfigured with the installation of freedom at its core'. The influence has gone in both directions: our ideas of what constitutes freedom change and these changes in turn influence the design of subsequent generations of new media objects, systems and tools.

I understand how naïve these arguments, or indeed how any continued belief in connections between new forms of liberty and the internet, can sound in the light of just how entwined networked technology has become in the formation of the 'control society'. It can be argued that the architecture of the net, far from being intrinsically supportive of autonomous networks of creativity and dissent is in effect the most powerful tool yet created for control and suppression. We can in fact go even further and argue as Alex Galloway has persuasively done in his book Protocol - subtitled How Control Exists after Decentralisation - 4 that the founding principal of the net has never been freedom but rather a new mode of control that is entirely native to networks. And that this controlling power lies not merely in an upgrade of the Benthamite Panopticon, but rather it is the technical protocols in and of themselves. They exercise control simply by virtue of the fact that they make the network connections (and critically the disconnections) possible. The equation is simple, no controlling technical protocol, no Internet. Power here is expressed through exclusion 


\section{CAT 2010 London Conference $\sim 3^{\text {rd }}$ February \\ David Garcia}

rather than exploitation or even surveillance. The signature application for the exercise of power in the control society is not CCTV camera but the password.

The implication of this argument is that it is not in the obvious cases such as the ease with which the totalitiarian regimes have gained control of the net, which should make us sceptical. Rather we must face the fact that concept of the net, as a space of freedom was always an illusion. The foundational modality of the net was never freedom but was, from the outset, a new and profound type of control. And the most sophisticated applications of this control are not to be found in the crude methods totalitarian states such as China, Iran or Belarus but in the so called 'open societies' of the west where the net is experienced as an open and seamless spatial continuity. To theorise the space constituted by the network society as the social scientist Manuel Castell's has done as a 'space of flows' is perhaps the biggest delusion of all and the most important narrative for artists and radical theorists of the net to confront and to explode.

We must question the idea that any meaningful democratic participation can be constituted simply though joining 'the big conversation' by becoming 'bloggers' or 'citizen journalists'. To do this may simply to become victims of what media theorist Jodie Dean describes as " communicative capitalism's perfect lure" in which "subjects feel themselves to be active, even as their every action reinforces the status quo.'... One needs look no further than the politics of scandal that surrounds Berlusconi to realise "that any revelation can be allowed, even celebrated and furthered, because its results remain ineffectual." 5

\section{WHAT CAN BE SAVED}

So can anything be recuperated from the utopian belief in freedom through openness? I believe it can if we look at the examples where the principles of free creative computing, are being applied in the grass roots and back alleys of radical new media culture.

Some years ago I put some of the arguments elucidated above for repudiating belief in the 'hacker ethic' of open media to an impressive group of pirate media activists in Brazil (Autolabs) 6, who work in the Favelas as educators creating computer networks and pirate radio channels out of re-cycled materials. They did not buy into my pessimistic narrative. "No!" they objected "for us technology and media are a vital battlefield particularly in Latin America where monopolistic media giants like Brazil's Globo pump out an endless narcotic diet of soaps, game shows and football that help to keep poor people passive" For these activists there is no imaginable political strategy that does not involve the expressive dimension 'language' (language in the widest sense) to articulate alternative futures. For these Brazilian activists the dichotomy between control and freedom I had presented was a false dichotomy. They argued that some important and radical definitions of freedom depend as much upon on control (often in the form of self governance) as they do upon absence of boundary or constraint. 
We can, they claimed, meaningfully connect freedom to democracy, not because we seek to dissolve all boundaries but because we seek the means to participate in determining where these boundaries (including laws and customs) might lie. Many of my discussions in recent years lead me to go further. I would claim that the identification, interrogation and re-articulation of boundaries, as a way of testing the limits of human freedom, has become the core subject of all advanced contemporary art, with or without computers.

\section{FREEDOM'S PLURALITY}

In 1958 in his justly famous inaugural lecture "Two Concepts of Liberty" the philosopher Isaiah Berlin made the crucial distinction between two concepts of liberty 7 - the positive and negative.

Alongside a basic negative freedom "the wish to be left alone to get on with my own life in my own way without being interfered with or coerced by others", Berlin described a quite different second concept of "positive liberty".

The idea of positive or self-directed freedom is founded on the principal of selfgovernance, the perceived wish of everyone to be their own master: 'I wish my life and decisions to depend on myself, not on external forces of what ever kind. I wish to be the instrument of my own, not of other men's acts of will'. From the perspective of 'positive liberty' structures, disciplines, systems and even bureaucracies should not automatically be seen as the antithesis of freedom.

Like language itself, a structure such as TCP/IP, DNS, and HTML, the protocols that make the Internet operational, do not only constrain, they also enable, by providing common framework. The proposition is as simple as it is paradoxical: no structure no freedom.

Despite the power of the radical critiques outlined in the opening paragraphs of this paper, the hacker ethic, with its ideal of freedom through 'openness' cannot, in the end, simply be dismissed as ideology. The foundation of these claims are at root epistemological. The ideal of openness represents an approach to knowing based on freedom to doubt based on an awareness of the provisional nature of all human knowledge. From this perspective discovery can only ever be about knowing more and more about what we do not know. Behind the ideal of openness is the drive to create a space not only for assertion but also for doubt and a degree of humility. Avoidance of the totalitarian disasters of the early $20^{\text {th }}$ century depend on the continuous awareness that knowledge is only ever partial and no verification is final. Zizek famously makes the distinction between 'knowing' and 'believing'. But neither knowing nor believing is enough. Assertions whether in contemporary art, politics or science have to be tested, every day, day after day, again and again. These are the constraints we must negotiate as we seek to re-imagine what constitutes creative freedom in conditions of pluralism. 


\section{References}

[1] CASTELLS, M: The Information Age: Economy, Society, and Culture Volume 1-. The Rise of the Network Society - 1996 Blackwells

[2] NELSON, T: Computer Lib: You can and must understand computers now / Dream Machines: New freedoms through computer screens - a minority report (1974), Microsoft Press, rev. edition 1987:

[3] BERLIN, I : 'From Hope and Fear Set Free', 1968

[4] GALlOWAY, A: Protocol, How Control Exists after Decentralisation, 2004, MIT Press

[5] J. DEAN: Publicity's Secret, 2002, Cornell University Press, Ithaca \& London.

[6] GARCIA, D: Mute, Culture and Politics After the Net. Autolabs Critiquing Utopia: 2005 http://www.metamute.org/en/Autolabs-Critiquing-Utopia

[7] BERLIN, I: Two Concepts of Liberty: was the inaugural lecture, University of Oxford, 1958. Published as Four Essays on Liberty Oxford University Press, 1969 